Wrocławskie Studia Wschodnie

$24(2020)$

Wydawnictwo Uniwersytetu Wrocławskiego

https://doi.org/10.19195/1429-4168.24.8

\author{
TOMASZ LANDMANN \\ ORCID: 0000-0002-9753-9373
}

Akademia Wojsk Lądowych im. gen. Tadeusza Kościuszki we Wrocławiu

\title{
Warunki i problemy funkcjonowania Polaków w wybranych odległych regionach Związku Sowieckiego w dokumentach Ambasady RP w Moskwie-Kujbyszewie w latach 1941-1943
}

\section{Wstęp. Zarys wybranej problematyki}

Celem przyjętym w artykule jest wskazanie wybranych problemów codziennego funkcjonowania ludności narodowości polskiej, która w latach 19391943 znalazła się w ZSRS. Cezurę czasową ograniczono do tych lat, uwzględniając czas od podpisania układu Sikorski-Majski w dniu 30 lipca 1941 roku aż do zerwania stosunków dyplomatycznych między ZSRS a Rządem RP na uchodźstwie 25 kwietnia 1943 roku. Ograniczono się do sytuacji osób w środkowej i wschodniej Syberii, a także Uzbeckiej SRR. W zakresie analiz dotyczących liczebności Polonii oraz zakładów opieki dla ludności polskiej prezentowane rozważania dotyczą całego obszaru ZSRS ${ }^{1}$.

Według danych z sowieckiego spisu ludności z 1937 roku ludność pochodzenia i narodowości polskiej stanowiła zaledwie 0,39\% składu narodowościowego Związku Sowieckiego. Jej liczbę oszacowano na około 636 tysięcy

$1 \mathrm{~W}$ artykule skupiono się na analizie archiwaliów z IPSM w Londynie. Zrezygnowano z materiałów znajdujących się w Archiwum Akt Nowych, ponieważ zostały one zebrane w jednym z wyczerpujących opracowań i stanowią odrębny, interesujący zbiór materiałów o losach Polonii w ZSRS. Por. Archiwalia Ambasady RP w Moskwie-Kujbyszewie (1941-1943) i Ministerstwa Informacji i Dokumentacji (1939-1945) w zbiorach Instytutu Hoovera w Stanfordzie. Informator, oprac. M. Filipiak, Warszawa 2002. 
osób ${ }^{2}$. W momencie agresji zbrojnej Sowietów na Polskę po 17 września 1939 roku w granicach Związku Sowieckiego znalazła się połowa przedwojennego obszaru II RP, co spowodowało, że pod panowanie sowieckie włączono terytorium zamieszkiwane przez mniej więcej 5,5 miliona Polaków ${ }^{3}$. Autor nie zamierza zajmować się analizą położenia ludności polskiej na podbitych przez Związek Sowiecki ziemiach tworzących przed 17 września 1939 roku wschodnie województwa II RP. Uwagę skupia na próbie wskazania wybranych problemów funkcjonowania polskiej diaspory w odległych obszarach wewnątrz Związku Sowieckiego na przykładzie obwodów sowieckich w środkowej i wschodniej Syberii, a także w Uzbeckiej SRR.

W piśmiennictwie podkreśla się, że kryterium etniczne i narodowościowe miało ważne znaczenie dla podziału administracyjnego kraju oraz w procesie centralnego sterowania przez Moskwę polityką narodowościową w Związku Sowieckim. W okresie dwudziestolecia międzywojennego autonomia narodowościowa poszczególnych mniejszości miała jedynie charakter fasadowy, a model polityki zmierzał w kierunku rozbudowanego, scentralizowanego aparatu represji ${ }^{4}$. W odniesieniu do działań wobec mniejszości, z uwzględnieniem diaspory polskiej, podstawową zasadą polityki rządów Związku Sowieckiego pozostała indoktrynacja środowisk narodowych oraz etnicznych ${ }^{5}$.

2 P. Eberhard, Geografia ludności Rosji, Warszawa 2002, s. 92; K. Jasiewicz, Europa nie prowincjonalna. Przemiany na ziemiach wschodnich dawnej Rzeczypospolitej w latach 1772 1999, Warszawa 1999, s. 976; A. Maryański, Przemiany ludnościowe w ZSRR, Warszawa 1995, s. 80; A. Srebrakowski, Liczba Polaków w ZSRR w świetle oficjalnych statystyk, [w:] Mniejszości narodowe i religijne w Europie Środkowo-Wschodniej w świetle statystyk XIX i XX wieku, red. J. Skarbek, Z. Sułowski, Lublin 1995, s. 83. Najdokładniejszy szacunek podaje liczbę Polaków mieszkających w 1937 roku na obszarze ZSRS na 636220 osób. Zob. Polacy w tagrach rosyjskiej pótnocy. W świetle relacji, listów i dokumentów, oprac. H. Owsiany, Warszawa 2000, s. 237. W rozważaniach pominięto wyniki spisu ludności ZSRS zorganizowanego w 1939 roku, ponieważ wskazuje się na spreparowanie jego wyników. Wiarygodność i dokładność wyników spisu z 1937 roku, jak również poprzedzającego go spisu z 1926 roku, bywają poddawane częściowo w wątpliwość. M. Iwanow, Polonia w Związku Radzieckim okresu międzywojennego. Kontrowersje wokół liczebności, „Dzieje Najnowsze” 19, 1997, nr 4, s. 48.

3 D. Boćkowski, Czas nadziei. Obywatele Rzeczypospolitej Polskiej w ZSRR i opieka nad nimi placówek polskich w latach 1940-1943, Warszawa 1999, s. 17. Według danych opracowanych przez Ministerstwo Informacji i Dokumentacji Rządu RP na emigracji dokładna liczba Polaków wyniosła 5274000 osób. Mały Rocznik Statystyczny Polski. Wrzesień 1939-czerwiec 1941, Londyn 1941, s. 9.

4 P. Eberhardt, Skład narodowościowy ludności Federacji Rosyjskiej na przełomie XX i XXI wieku, „Studia z Geografii Politycznej i Historycznej” 5, 2016, s. 211.

5 A. Krochmal, Polacy i polskie dziedzictwo kulturowe $w$ krajach Europy Wschodniej (cz. 6). Sytuacja Polaków od rewolucji bolszewickiej do 1939 r., „Cenne. Bezcenne. Utracone” 2008 , nr 1, s. 34. Nasilone działania w ramach indoktrynacji i represji były motywowane między innymi troską o ochronę rozwoju podstaw ustroju socjalistycznego i komunizmu na całym obszarze podbitym przez Związek Sowiecki. Moskwa uzasadniała dalsze represje także ze wzglę-

Wrocławskie Studia Wschodnie 24, 2020

(C) for this edition by CNS 


\section{Kwestie sporne wokół liczebności polskiej diaspory w ZSRS w latach 1939-1943}

W kontekście obecności ludności polskiej na obszarze Związku Sowieckiego nie można pominąć szczególnie istotnego faktu, jakim była akcja deportacji ludności prowadzona przez władze sowieckie systematycznie po wybuchu II wojny światowej ${ }^{6}$. Stan faktyczny diaspory polskiej na terenie ZSRS był w dużej mierze konsekwencją akcji deportacyjnej prowadzonej przez ZSRS wobec ludności polskiej od lutego 1940 do czerwca $1941 \mathrm{roku}^{7}$. $\mathrm{Z}$ danych zawartych $\mathrm{w}$ dokumencie przedstawionym przez Ambasadę RP w Waszyngtonie Departamentowi Stanu USA w marcu 1945 roku wynikało, że w odniesieniu do samej tylko ludności rdzennie polskiej akcja deportacyjna dotyczyła około 400 tysięcy osób ${ }^{8}$. Inne źródła redukowały liczę deportowanych do ponad 300 tysięcy. Dużą grupę deportowanych stanowili mieszkający w Polsce Żydzi (około 600 tysięcy). Łączna liczba deportowanych w głąb Związku Sowieckiego - uzupełniona o dobrowolnych uciekinierów — jest

du na przeciwstawienie się oddolnym ruchom narodowościowym i etnicznym w Związku Sowieckim, które miały grozić integralności terytorialnej państwa i być skierowane na odbudowę samodzielnej państwowości narodów podbitych. Przykładem może być tak zwany ruch prometejski, w którego wspieranie zaangażowała się Polska już po 1921 roku i nie zaniechała działań — realizowanych z pozycji emigracji niepodległościowej — również po wybuchu II wojny światowej. Obszerniej na temat znaczenia i kierunków ruchu prometejskiego w okresie II wojny światowej zob. M. Kwiecień, Kilka dokumentów z dziejów ruchu prometejskiego lat drugiej wojny światowej, „Krakowskie Studia z Historii Państwa i Prawa” 7, 2014, nr 2, s. 335-347; T. Landmann, Prometeizm jako założenie polityczno-ideologiczne w korespondencji Polskiej Grupy Prometeusza w Londynie w pierwszych latach po II wojnie światowej, „Wschodnioznawstwo" 2018, nr 12, s. 261-277; S. Łukasiewicz, Prometeizm na emigracji w pierwszych latach po II wojnie światowej w świetle materiałów wywiadu komunistycznego Polski Ludowej, [w:] Ruch prometejski i walka o przebudowę Europy Wschodniej (1918-1940). Studia i szkice, red. M. Kornat, Warszawa 2012, s. 309-326; L. Wyszczelski, Rozpruwanie Rosji. Prometeizm - idea i realizacja, Warszawa 2016, s. 283-290.

${ }^{6}$ Główne cele akcji wysiedleń i deportacji sprowadzały się do pomnożenia zasobów siły roboczej pracującej, zazwyczaj przymusowo, na rzecz Związku Sowieckiego, a także pozbycia się z regionów przygranicznych, to jest niedawnych województw wschodnich II RP, osób niepewnych, podejrzanych, a także takich, których działalność mogła stanowić zagrożenie dla sowieckich interesów politycznych. U. Brewczyńska-Wiktor, Mniejszość polska w Rosji-geneza i wspótczesność, „Studia i Badania Naukowe. Europeistyka” 2014, nr 2, s. 64.

7 S. Leończyk, Mała Minusa w Kraju Krasnojarskim jako miejsce pamięci deportacji narodu polskiego, „Niepodległość i Pamięć” 2017, nr 1, s. 157. Na temat dokładniejszych zmian stanu liczebnego ludności zob. D. Boćkowski, Masowe deportacje polskiej ludności w głąb ZSRR w latach 1940-1941: próba weryfikacji danych, „Mazowieckie Studia Humanistyczne” 1996, nr 2/1, s. 41-51.

8 Deportacje we wschodniej Europie z wydawnictwa „Russian Affairs” [marzec 1945] z dnia 4 kwietnia 1945 roku, AIJP w Ameryce, Samodzielna Placówka Wywiadowcza ESTEZET, teczka: 701/111/17.

Wrocławskie Studia Wschodnie 24, 2020

(C) for this edition by CNS 


\section{szacowana nawet do 1,2 miliona osób ${ }^{9}$, z czego same tylko deportacje do pracy przymusowej miały dotyczyć około jednej trzeciej populacji ${ }^{10}$.}

9 Identyczną liczbę deportowanych z Polski w okresie tak zwanych czterech faz nasilonej akcji deportacyjnej, to jest od lutego 1940 do czerwca 1941 roku, przedstawiono w literaturze przedmiotu. Oszacowano, że maksymalna liczba przesiedlonych wyniosła przeszło 1,2 miliona osób, głównie obywateli polskich z województw wschodnich II RP. W. Śladkowski, Wychodźstwa polskiego zarys dziejowy, Lublin 1994, s. 62. Jak zauważył A. Patek, liczba ta nie uwzględnia jednak licznych wśród Polaków ofiar wysiedleń i deportacji organizowanych przez Sowietów po napaści zbrojnej z 17 września 1939 roku. A. Patek, Polska diaspora w Rosji Radzieckiej i ZSRR, [w:] Polska diaspora, red. D. Bartkowiak, A. Walaszek, Kraków 2001, s. 301. W literaturze kładzie się nacisk, że wśród deportowanych do ZSRS w latach 1940-1941 znalazło się stosunkowo dużo dzieci. Ich liczba sięgała 158 tysięcy. Wiele spośród nich umieszczono w sowieckich domach dziecka. J. Lachowicz, Los dzieci polskich w ZSRR w czasie II wojny światowej, [w:] Położenie ludności polskiej na terytorium ZSRR i wschodniej ziemiach Rzeczypospolitej w czasie II wojny światowej, red. A. Marszałek, Toruń 1990, s. 112-113. A. Czubiński zawyża tę liczbę nawet do 1,7 miliona osób. A. Czubiński, Dzieje najnowsze Polski do roku 1945, Poznań 1994, s. 613. Znaczna część przesiedleńców była ofiarami masowych aresztowań „wrogów komunizmu i ZSRS” o charakterze zorganizowanej akcji prowadzonej na ziemiach wschodnich byłej II RP od września 1939 roku do czerwca 1941 roku. D. Matelski, Polityka eksterminacji obywateli Drugiej Rzeczypospolitej przez Trzecia Rzesze i Zwiazek Sowiecki w latach 1939-1945, „Nowa Polityka Wschodnia” 2017, nr 4, s. 211. Z większą rezerwą i powątpiewaniem należy odnosić się do prezentowanych w literaturze danych, z których wynika, że akcja przesiedleńcza i deportacyjna miała dotyczyć od 1,8 do 2,5 miliona ludności, przy czym szacunki te uwzględniają wyjazdy zarówno w głąb Związku Sowieckiego, jak i Azji Środkowej, na przykład rozwój liczebny diaspory polskiej w Mandżurii. H. Kubiak, Mniejszości polskie i Polonia w ZSRR, Wrocław 1992, s. 434. Intensywność działań sowieckich może dodatkowo obrazować fakt, że tylko w okresie od września do końca grudnia 1939 roku Związek Radziecki deportował w głąb swojego terytorium od 750 tysięcy do 1,5 miliona osób, w tym - według największych szacunków — do 180 tysięcy jeńców narodowości polskiej. J. Czerniakiewicz, Przemieszczenia ludności polskiej z ZSRR 1944-1959, Warszawa 2004, s. 24. Z kolei w schyłkowym okresie II wojny światowej prześladowania sowieckie i deportacje w głąb Związku Sowieckiego w dalszym ciągu dotyczyły nie tylko ludności polskiej, ale również narodów z Europy Środkowo-Wschodniej czy państw nadbałtyckich. Prowadzona przez Sowietów polityka eksploatacyjna podbitych ziem przyczyniła się do sytuacji, zgodnie z którą — w efekcie licznych deportacji — rosła liczba osób z pobitych państw, które były zmuszone przebywać na obszarze Związku Sowieckiego. Z zachowanych archiwaliów wynika na przykład, że tylko w 1944 roku Armia Czerwona i NKWD deportowały, głównie na Syberię i Ural, około 50 tysięcy osób narodowości litewskiej. Tłumaczenie artykułu pt. Deportacja Litwinów z wydawnictwa „Russian Affairs” [październik 1944] z dnia 20 grudnia 1944 roku, AIJP w Ameryce, Samodzielna Placówka Wywiadowcza ESTEZET, teczka: 701/111/16. Akcja deportacyjna ludności z Polski, krajów nadbałtyckich, a także Bałkanów, nie ustała w miesiącach wiosennych 1945 roku, obejmując dodatkowo początek deportacji ludności niemieckiej. Tłumaczenie artykułu pt. Deportacje we wschodniej Europie z wydawnictwa „Russian Affairs” [marzec 1945] z dnia 4 kwietnia 1945 roku, AIJP w Ameryce, Samodzielna Placówka Wywiadowcza ESTEZET, teczka: 701/111/17.

${ }^{10}$ K. Kersten, Szacunek strat osobowych w Polsce Wschodniej, „Dzieje Najnowsze” 24, 1994, nr 2, s. 46. Dla uwiarygodnienia przywołanych statystyk można wskazać, że w połu-

Wrocławskie Studia Wschodnie 24, 2020

(C) for this edition by CNS 
Szacunki opracowane na podstawie dokumentów archiwalnych zgromadzonych w IPMS w Londynie wskazują, że przed końcem kwietnia 1943 roku na obszarze ZSRS znalazło się 271325 obywateli narodowości polskiej, z czego około 49\% stanowili mężczyźni, a 51\% kobiety. Największe skupiska ludności polskiej występowały w syberyjskich regionach państwa sowieckiego, głównie na obszarze Kraju Ałtajskiego (17 429 osób) oraz Kraju Krasnojarskiego (12 684 osoby), a także w takich jednostkach administracyjnych, jak Kazachska SRR (zwłaszcza obwód żambylski — 15817 osób, północny Kazachstan - 12839 osób oraz obwód akmolski - 12224 osoby), Uzbecka SRR na terenie obwodu samarkandzkiego (11 512 osób). Obecność najliczniejszej diaspory polskiej na obszarze Komijskiej Autonomicznej SRR (11 661 osób $)^{11}$ odnotowano w europejskiej części ZSRS.

Przedstawione szacunki znacząco odbiegają od przedstawionych wcześniej w artykule na podstawie nowych ustaleń piśmiennictwa naukowego. Różnicę można tłumaczyć zarówno niekompletnymi danymi pracowników polskich placówek pomocowych dla zesłańców do ZSRS, jak i efektami procesu przymusowej paszportyzacji, zainicjowanego przez władze sowieckie od wiosny 1940 roku $^{12}$. Równie ważnym czynnikiem była dynamika wędrówek obywateli polskich z jednych rejonów ZSRR do innych i wymykanie się ewidencji przez dużą część ludności. Przy zbieraniu danych na potrzeby opracowania statystycznego nie można pominąć uwarunkowań związanych z — niezależnymi od polskich placówek dyplomatycznych — trudnościami organizacyjnymi ${ }^{13}$.

dniowej części Kazachskiej SRR około 80\% polskiej ludności cywilnej było zmuszonych na przełomie 1941 i 1942 roku do pracy w kołchozach. Polacy wysyłani do kołchozów znajdowali się „w bardzo złym stanie zdrowia, wyczerpani fizycznie, nawet więc po zatrudnieniu nie mogli pracować intensywnie". A.C. Dobroński, Raport o Polakach na południu Kazachstanu, „Zesłaniec” 2008, nr 35, s. 34.

11 Wykaz stanu liczebnego i rozmieszczenia obywateli polskich w ZSRR w poszczególnych rejonach dnia 25 kwietnia 1943 roku, IPMS w Londynie, Ambasada RP w Kujbyszewie, A.7/307/30.

12 Proces paszportyzacji dotyczył wprowadzenia obowiązku wydawania dowodów osobistych w formie tak zwanych paszportów wewnętrznych dla ludności z części ziem anektowanych przez Sowietów po wybuchu II wojny światowej (najpierw obywateli zachodnich części Białoruskiej i Ukraińskiej SRR). Działania miały charakter przymusowej asymilacji opartej na nadawaniu obywatelstwa radzieckiego. Przepisy wykonawcze do procesu paszportyzacji były efektem działań podjętych przez NKWD, co świadczyło o szczególnej randze aktywności realizacji sowieckiej polityki wewnętrznej. T. Bereza, Represje NKWD wobec mieszkańców strefy przygranicznej 1939-1941, „Biuletyn IPN” 2001, nr 7, s. 32.

13 Wykaz stanu liczebnego i rozmieszczenia obywateli polskich w ZSRR w poszczególnych rejonach dnia 25 kwietnia 1943 roku, IPMS w Londynie, Ambasada RP w Kujbyszewie, A.7/307/30. 


\section{Zakłady opieki dla ludności polskiej w ZSRS}

Obecność licznej diaspory polskiej na terenie ZSRS wymagała podjęcia akcji pomocowej dla potrzebujących rodzin. Uwzględniając okres trwający w warunkach amnestii po układzie Sikorski-Majski z 30 lipca 1941 roku i po wznowieniu stosunków dyplomatycznych między rządem sowieckim a Rządem RP na uchodźstwie, polskie placówki dyplomatyczne koordynowały oraz monitorowały proces niesienia pomocy przesiedleńcom $\mathrm{w}$ głąb ZSRS $^{14}$. Formalnie w opiekę nad obywatelami włączono Ambasadę RP w Moskwie (dnia 1 listopada 1941 roku przeniesioną do Kujbyszewa), dwadzieścia delegatur i podporządkowaną sieć mężów zaufania ${ }^{15}$.

Szczególnie ważnym aspektem związanym z obecnością Polaków na obszarze ZSRS było organizowanie dla nich zakładów opieki w różnej postaci. Podanie pełnych i niebudzących wątpliwości szacunków na temat liczby zakładów opieki jest trudne do ustalenia. Opierając się na dokumentach opracowanych przez Ambasadę RP w Kujbyszewie, można podać dane z lutego 1943 roku (tabela 1).

Z przedstawionych danych wynika, że w lutym 1943 roku na obszarze ZSRS funkcjonowało ponad 800 zakładów opieki. Z działań placówek skorzystało wówczas niespełna 31,5 tysiąca osób. Najwięcej placówek to punkty dożywiania (176) i przedszkola (175), przy dużym udziale sierocińców (83), ambulatoriów (76) i placówek zajmujących się organizacją kursów języka polskiego, historii i geografii dla Polonii (68).

Ze względu na geograficzne regiony rozmieszczenia zakładów opieki dla Polaków w ZSRS najwięcej placówek funkcjonowało w południowych obwodach kraju (394 zakłady obsługujące 14794 osoby), następnie na obszarze Syberii (174 zakłady obsługujące 9527 osób), przy niewielkiej różnicy dla tej ostatniej w porównaniu do placówek funkcjonujących na terenie Kazachskiej SRR (162 zakłady, w których pomoc uzyskało 4623 Polaków). We wszystkich zakładach opieki zatrudnionych pozostawało 2539 osób ${ }^{16}$.

14 S. Ciesielski, Polacy w Kazachstanie 1940-1946. Zesłańcy lat wojny, Wrocław 1997, s. 7.

15 D. Boćkowski, Masowe..., s. 43-44; R. Buczek, Działalność opiekuńcza Ambasady RP w ZSRR w latach 1941-43, „Zeszyty Historyczne” 1974, nr 29, s. 52; J. Siedlecki, Losy Polaków w ZSRR w latach 1939-1986, Londyn 1988, s. 96; P. Żaroń, Armia Polska w ZSRR, na Bliskim i Środkowym Wschodzie, Warszawa 1981, s. 159. Z zachowanych archiwaliów wynika, że działania Ambasady RP w Moskwie na rzecz pomocy Polonii w ZSRS objęły również obywateli polskich pochodzenia żydowskiego. Działania pomocowe były komplementarne wobec otrzymywanych od żydowskich organizacji pomocowych mających siedzibę w Stanach Zjednoczonych, takich jak Jewish Labour Committee, American Jewish Joint Distribution Committee czy American Federation for Polish Jews. Udzielona pomoc i opieka nad ludnością żydowską w ZSRR [sierpień 1943], IPMS w Londynie, Ambasada RP w Kujbyszewie, A.7/307/40.

16 Wykaz zakładów opieki Ambasady RP w ZSRR z dnia 16 lutego 1943 roku, IPMS w Londynie, Ambasada RP w Kujbyszewie, A.7/307/31.

Wrocławskie Studia Wschodnie 24, 2020

(C) for this edition by CNS 
Tabela 1. Wykaz zakładów opieki dla Polaków przebywających w ZSRS w lutym 1943 roku

\begin{tabular}{|l|c|c|}
\hline \multicolumn{1}{|c|}{ Rodzaj zakładu opieki } & $\begin{array}{c}\text { Liczba zakładów } \\
\text { opieki }\end{array}$ & $\begin{array}{c}\text { Liczba osób } \\
\text { objętych pomocą }\end{array}$ \\
\hline sierocińce & 83 & 5364 \\
\hline domy inwalidów & 58 & 1976 \\
\hline domy noclegowe & 13 & 719 \\
\hline domy rekonwalescentów & 5 & 192 \\
\hline szpitale & 5 & 145 \\
\hline przedszkola & 175 & 5685 \\
\hline szkoły & 43 & 2999 \\
\hline $\begin{array}{l}\text { placówki organizujące kursy z języka } \\
\text { polskiego, historii i geografii }\end{array}$ & 68 & 1466 \\
\hline punkty dożywiania & 176 & 10754 \\
\hline stołówki & 15 & 2100 \\
\hline żłobki & 76 & - \\
\hline ambulatoria & 41 & - \\
\hline punkty sanitarne & 1 & - \\
\hline laboratoria & 47 & 31405 \\
\hline $\begin{array}{l}\text { różne warsztaty (krawieckie, stolarskie, } \\
\text { szewskie, fryzjerskie itp.) }\end{array}$ & 807 & - \\
\hline Razem & & - \\
\hline
\end{tabular}

Źródło: Wykaz zakładów opieki Ambasady RP w ZSRR z dnia 16 lutego 1943 roku, IPMS w Londynie, Ambasada RP w Kujbyszewie, A.7/307/31.

Należy dodać, że główne obszary działań Ambasady RP w ZSRR w ramach systemu zakładów opieki nad obywatelami polskimi dotyczyły: wypłacania zapomóg finansowych, utrzymywania i finansowania zakładów opiekuńczych Ambasady RP, gwarantowania dostępu do opieki zdrowotnej, ułatwiania ewakuacji poza granice ZSRS, a także niesienia pomocy kulturalno-oświatowej ${ }^{17}$.

Nie można pominąć licznych trudności w funkcjonowaniu wspomnianych zakładów opieki dla Polaków na terenie ZSRS. Podkreśla się chociażby, że liczba zakładów istotnie się przeobrażała. Stałe oraz względnie stabilne funkcjonowanie dotyczyło wyłącznie sierocińców i domów inwalidów. Byt pozostałych rodzajów placówek zależał od wielu zmieniających się okoliczności, w tym zwłaszcza możliwości uzyskania tak zwanych fondów, czyli przydziału produktów od władz sowieckich po cenach państwowych, szansy nabycia produktów

17 Sprawozdanie Działu Opieki Społecznej Ambasady RP w ZSRR na dzień 1 grudnia 1942 roku, IPMS w Londynie, Ambasada RP w Kujbyszewie, A.7/307/43. Sprawozdanie A. Pająka, delegata Ambasady RP w ZSRR na Jakucką ASRR, za okres 19 września 194131 stycznia 1942 roku, IPMS w Londynie, Ambasada RP w Kujbyszewie, A.7/307/5.

Wrocławskie Studia Wschodnie 24, 2020

(C) for this edition by CNS 
na rynku, a także ich dostępności na podstawie przydziałów ze strony polskich placówek dyplomatycznych. Istniała ponadto trudność w dostosowaniu pomieszczeń wielu zakładów opieki do panujących w ZSRS warunków klimatycznych, zwłaszcza mrozów. Wiele przedszkoli i szkół na okres zimowy likwidowano ${ }^{18}$.

W archiwaliach zachowały się wzmianki świadczące o próbie wykorzystania przez emigracyjne władze polskie pomocy zagranicznej w usprawnieniu systemu opieki nad Polakami przebywającymi na terenie ZSRS. Przykładem była wzmianka poczyniona w depeszy MSZ do Prezydium Rady Ministrów Rządu RP na uchodźstwie z dnia 24 marca 1942 roku, informująca o pozyskaniu 12 tysięcy dolarów amerykańskich z Watykanu celem pokrycia kosztów akcji umieszczenia dzieci polskich z ZSRS w katolickich instytucjach w Persji. Akcja miała trwać 6 miesięcy i objąć 200 dzieci polskich, które miały zostać umieszczone $\mathrm{w}$ schronisku prowadzonym przez biskupa angielskiego w perskiej miejscowości Isfahan. W depeszy znalazła się także wzmianka na temat realizowanej równolegle akcji umieszczenia 500 dzieci z polskich rodzin z ZSRS w Indii ${ }^{19}$. We współpracę z rządem emigracyjnym zaangażowali się członkowie Polskiego Czerwonego Krzyża ${ }^{20}$.

18 Wykaz zakładów opieki Ambasady RP w ZSRR z dnia 16 lutego 1943 roku, IPMS w Londynie, Ambasada RP w Kujbyszewie, A.7/307/31. W literaturze wykazywano liczne niedociągnięcia $\mathrm{w}$ zaspokajaniu podstawowych potrzeb życiowych ludności polskiej zesłanej w odleglejsze rejony ZSRS po wybuchu II wojny światowej. Na przykładzie działań Ambasady RP w Kujbyszewie, reprezentatywnych również dla innych placówek funkcjonujących w ZSRS, zwrócono uwagę, że za taki stan rzeczy odpowiadały w szczególności braki kadrowe oraz nieznajomość realiów, w których przyszło żyć polskim zesłańcom. D. Boćkowski, Działalność ambasady RP w Kujbyszewie oraz jej delegatur i placówek mężów zaufania w świetle raportów NIK Rządu RP w Londynie, „Studia z Dziejów Rosji i Europy Środkowo-Wschodniej" 32, 1997, s. 204. Występowały problemy w zakupie i zaopatrywaniu ludności polskiej z poszczególnych obwodów sowieckich w produkty ze względu na znaczną liczebność Polaków, trudności w transporcie towarów, jak również w wielu punktach sceptyczny czy bierny stosunek władz sowieckich do działań pomocowych ze strony mężów zaufania dla ludności polskiej. A. Kaniewska, op. cit., s. 116.

19 Protokoły Komisji dla Spraw Sowieckich. Depesze do placówek, IPMS w Londynie, Prezydium Rady Ministrów. Archiwum Kancelarii 1939-1990, PRM.K. 19. O roli Watykanu w niesieniu pomocy polskim zesłańcom w głąb ZSRS pisze także D. Boćkowski, wskazując na przeważający aspekt pomocy pieniężnej. Autor nie wskazuje jednak dokumentów, w których można znaleźć dokładniejsze informacje choćby na temat wysokości pomocy płynącej z Watykanu. Stwierdza zarazem: „O tym, że rola Stolicy Apostolskiej w pomocy ludności zesłańczej mogła być znacząca, świadczyć może specjalne podziękowanie ambasadora T. Romera we wstępie do pracy »Zesłańcy polscy w ZSRR«”. D. Boćkowski, Dyplomacja Rządu Drugiej Rzeczypospolitej na uchodźstwie wobec kwestii polskiej w ZSRR w latach 1939-1945, [w:] Z dziejów polskiej stużby dyplomatycznej i konsularnej, red. J. Faryś, M. Szczerbiński, Gorzów Wielkopolski 2005, s. 144.

20 Wykorzystano zaangażowanie Polskiego Czerwonego Krzyża na rzecz pomocy obywatelom polskim w ZSRS, głównie przymusowo przesiedlonym w czasie akcji deportacyjnej z lat 1940-1941. Członkowie PCK dysponowali bowiem informacjami i mapami na temat miejsc

Wrocławskie Studia Wschodnie 24, 2020

(C) for this edition by CNS 


\section{Problemy w codziennej egzystencji rodzin polskich w środkowej Syberii}

Szczególnie trudne warunki życiowe Polaków przebywających na terenie ZSRS występowały w regionie Syberii — środkowa Syberia, obwody kemerowski i nowosybirski, Kraj Ałtajski. Rejony te w marcu 1943 roku zamieszkiwało przez około 28 tysięcy obywateli polskich, głównie wysiedlonych siłą z RP w latach 1940-194121. W archiwaliach zachowały się informacje o licznych skargach kierowanych w listach przez obywateli polskich do Ambasady RP w Kujbyszewie. Wskazywano zwłaszcza na brak opału (Kraj Ałtajski cechował bardzo niski wskaźnik lesistości), niedostateczną liczbę mieszkań (konieczność życia w ziemiankach lub przerobionych na mieszkania starych wagonach kolejowych ${ }^{22}$, brak odzieży i obuwia niezbędnych do wykonywania pracy przy wyrębie lasów oraz w kołchozach ${ }^{23}$, wstrzymywanie zapłaty za pracę w zakładach sowieckich, przypadki niedożywienia, a nawet śmierci głodowej. Warto dodać, że normy żywnościowe dla polskiego robotnika w środkowej Syberii oszacowano w przedziale od 0 do 800 gramów chleba na dzień, przy dostrzeżeniu daleko idących dysproporcji dla przedsiębiorstw przemysłowych oraz rolniczych na niekorzyść pracowników tych drugich. Odnotowano zarazem przypadki malarii, dyzenterii, gruźlicy oraz odry. Wobec obywateli polskich stosowano w formie represyjnej przepisy sowieckiej usta-

zesłania i adresów, pod którymi przebywały rodziny polskie. Informacje te były cenne dla Rządu RP na uchodźstwie oraz jego placówek dyplomatycznych, w tym Ambasady RP w Kujbyszewie. Obszerniej na ten temat zob. M. Wieliczko, Rozpoznanie przez Polski Czerwony Krzyż losu Polaków w Związu Radzieckim (listopad 1939-lipiec 1941 roku), [w:] Mniejszości polskie i Polonia w ZSRR, red. H. Kubiak et al., Kraków-Warszawa-Wrocław 1992, s. 287-300.

21 Główną warstwą społeczną byli rolnicy z Kresów Wschodnich, głównie przesiedleńcy z Wileńszczyzny, Lubelszczyzny, Polesia, Wołynia, niedawnego województwa białostockiego, natomiast w mniejszej liczebności osoby z województw lwowskiego i tarnopolskiego. W grupie inteligencji polskiej największy udział wśród przesiedleńców stanowili z kolei nauczyciele. Położenie ludności polskiej w środkowej Syberii. Sprawozdanie z dnia 29 marca 1943 roku, IPMS w Londynie, Ambasada RP w Kujbyszewie, A.7/307/42.

22 Wśród innych częstych problemów charakteryzujących warunki mieszkaniowe ludności polskiej na Syberii wymienia się powszechną obecność wszelkiego rodzaju robactwa, brak oświetlenia, zwłaszcza w zimie z racji niewystarczających przydziałów paliwa do lamp naftowych i problemy z uzyskaniem opału poza rejonami dobrze zalesionymi. A. Pankiewicz, Sytuacja polskich zesłańców na Syberii w okresie II wojny światowej, „Zesłaniec” 2016, nr 66, s. 68.

23 Podkreśla się, że przywiezione z Polski przez zesłańców na Syberię odzież i obuwie nie odpowiadały warunkom panującym w tamtejszym klimacie. Część osób dodatkowo sprzedała swoje ubrania miejscowej ludności, aby zakupić żywność. Co więcej, wielu pracującym w kołchozach i gospodarstwach leśnych w ogóle nie wydano ubrań i obuwia, co pogarszało warunki, w których Polacy musieli pracować w poszczególnych obwodach sowieckich na Syberii. S. Ciesielski, G. Hryciuk, Warunki egzystencji, [w:] Życie codzienne polskich zesłańców w ZSRR w latach 1940-1946, red. S. Ciesielski, Wrocław 1997, s. 113-114.

Wrocławskie Studia Wschodnie 24, 2020

(C) for this edition by CNS 
wy o dyscyplinie pracy, dopuszczając się bezprawnych wyroków sądowych za rzekome łamanie dyscypliny. Pojawiły się również wzmianki na temat wrogiego nastawienia mniejszości ukraińskiej do Polaków, co utrudniało koegzystencję Polonii w ramach społeczeństwa środkowej Syberii ${ }^{24}$.

$\mathrm{Na}$ obywateli polskich mieszkających w środkowej Syberii nałożono ponadto obciążenia finansowe tradycyjnie przewidziane jedynie dla obywateli sowieckich, co było przejawem dyskryminującego traktowania i ekonomicznego ucisku ludności polskiej. Oprócz konieczności uiszczania podatków ogólnych, w tym dochodowego, kulturalnego i nadzwyczajnego w formie pożyczek wojennych, w niektórych rejonach obywateli polskich zmuszano do płacenia podatku wojennego, mimo że miał on - w myśl sowieckiego ustawodawstwa - obowiązywać wyłącznie obywateli sowieckich. W części kołchozów Polacy musieli płacić dodatkowy podatek, tak zwany postawek, to jest świadczenie $\mathrm{w}$ naturze, przewidziane $\mathrm{w}$ myśl prawa dla obywateli sowieckich, którzy posiadali gospodarstwa podręczne i zwierzęta gospodarskie, mimo nieposiadania gospodarstw i zwierząt gospodarskich ${ }^{25}$.

\section{Wybrane przykłady i trudności w położeniu rodzin polskich we wschodniej Syberii}

Z wieloma problemami ludność narodowości polskiej musiała zmagać się także na obszarze wschodniej Syberii, w tym Jakuckiej Autonomicznej SRR, obwodu irkuckiego i obwodu czytyjskiego. Wymienione regiony sowieckiego państwa zamieszkiwało na przełomie 1942 i 1943 roku niespełna 10 tysięcy obywateli polskich, z czego ponad osiem tysięcy żyło w obwodzie irkuc-

24 Interesująco przedstawiała się także kwestia mobilizacji obywateli polskich do Armii Czerwonej. Przypadki wzywania obywateli polskich do Armii Czerwonej pojawiły się w miejscowościach Tiasul, w obwodzie kemerowskim, i Tiażyn, w obwodzie nowosybirskim, w sierpniu i wrześniu 1942 roku. Za każdym razem przedstawiciele Polonii powoływali się na obywatelstwo polskie i przysługujące im prawa amnestyjne, prosząc dodatkowo Ambasadę RP w Kujbyszewie o interwencję w ich sprawie. Władze sowieckie nie były w stanie skutecznie przeprowadzić mobilizacji, ostatecznie wycofując się z tej praktyki na trzech wymienionych obszarach środkowej Syberii (ibidem). Należy wzmiankować, że powoływanie się na prawa amnestyjne przy odmowie służby wojskowej na rzecz Armii Czerwonej było uzasadnione faktem wprowadzenia amnestii dla obywateli polskich żyjących w ZSRS po podpisaniu układu Sikorski-Majski w lipcu 1941 roku. Interpretacja przepisów amnestyjnych przez Sowietów miała charakter selektywny, co pozwalało władzom na daleko idące nadużycia i dalsze represje pod adresem Polonii w ZSRS. P. Żaroń, Ludność Polska w Zwiąku Radzieckim w czasie II wojny światowej, Warszawa 1990, s. 186.

25 Położenie ludności polskiej w środkowej Syberii. Sprawozdanie z dnia 29 marca 1943 roku, IPMS w Londynie, Ambasada RP w Kujbyszewie, A.7/307/42. 
kim, a niemal 1,6 tysiąca w Jakuckiej ASRR. Udział Polaków w strukturze narodowościowej obwodu czytyjskiego był marginalny (38 osób, według danych pozostających w posiadaniu Ambasady RP w Kujbyszewie). W obwodzie irkuckim przeważali Polacy będący rolnikami (około 60\% populacji), w dwóch pozostałych regionach sowieckich ludność polska to głównie inteligencja i rzemieślnicy różnych specjalności ( $90 \%$ populacji). Warunki życiowe ludności określono jako ciężkie. Wielu Polaków było zmuszonych mieszkać w barakach służących wcześniej do przetrzymywania więźniów sowieckich. W pracy natomiast podstawą utrzymania ludności zatrudnionej $\mathrm{w}$ przedsiębiorstwach leśnych — $\mathrm{z}$ racji przewagi przemysłu drzewnego w produkcji w opisywanych regionach - był chleb w porcjach od 600 do 800 gramów i wydawana 2-3 razy dziennie półlitrowa porcja zupy na osobę. Średni przydział mąki dla pracownika kołchozu w rejonach wschodniej i północno-wschodniej Syberii oszacowano na 100-200 gramów, najwyższy przydział nie przekraczał 600 gramów. Zarządzający nie wydawali przydziału na niepracujących członków rodziny osoby wykonującej pracę w kołchozie. Z przydziałów wykluczono starców, inwalidów, dzieci, a okresowo również osoby chore. Jednocześnie władze sowieckie represjonowały ludność polską uchylającą się od pracy, pozbawiając racji chleba, a także przez zimową przymusową mobilizację do prac leśnych. W ramach represji część rodzin polskich nie otrzymała zaświadczeń amnestyjnych, w praktyce nie mogąc swobodnie poruszać się wewnątrz kraju ${ }^{26}$.

W efekcie ciężkich warunków mieszkaniowo-żywnościowych ludność polska we wschodniej Syberii zmagała się z wieloma chorobami, odnotowano gruźlicę, malarię, rachityzm u dzieci, jaglicę, tyfus plamisty i dur brzuszny. Charakterystyczne problemy zdrowotne ludności polskiej żyjącej w obwodzie irkuckim zawarto w jednym ze sprawozdań tamtejszego lekarza, dr. Witolda Funka, pracującego w rejonie tajszeckim. We wrześniu 1942 roku lekarz udzielił 288 porad lekarskich, stwierdzając 13 przypadków chorób zakaźnych, dwa przypadki awitaminozy, trzy osoby chore na gruźlicę oraz 191 pacjentów z innymi chorobami. Warunki higieniczne doktor określił jako opłakane. Wskazał na niedostatek wody pitnej i donoszenie wody z potoków w związku z wydanym przez władze rejonu zakazem korzystania ze studni. Odnotowano brak leków, zwłaszcza preparatów nasercowych, salicylowych i materiałów opatrunkowych. Niezaspokajanie dziennych potrzeb żywnościowych prowadziło do występowania obrzęków głodowych. Większość osób, zwłaszcza dzieci i młodzież, zmagała się z niedokrwistością. Pojawiało się

26 Położenie ludności polskiej we wschodniej Syberii. Sprawozdanie z dnia 28 lutego 1943 roku, IPMS w Londynie, Ambasada RP w Kujbyszewie, A.7/307/41. 
także „osłabienie ogólne graniczące z wyniszczeniem. [...] Szereg dzieci przestało chodzić wskutek cofnięcia się procesów rozwojowych systemu kostnego i zapadło na krzywicę"27.

Na przykładzie polityki władz sowieckich w rejonie tajszeckim w obwodzie irkuckim odnotowano również represjonowanie ludności polskiej deklarującej wiarę katolicką, oferując lepsze prace obywatelom polskim pochodzenia żydowskiego oraz wyznania prawosławnego. Dopiero po amnestii dopuszczono możliwość nauczania dzieci polskich w języku polskim, wcześniej zmuszanych do nauki w szkole sowieckiej w celu wykorzenienia wartości patriotycznych i religijnych ${ }^{28}$. Na przykładzie sytuacji polskich rodzin żyjących na obszarze Jakuckiej ASRR oszacowano, że zarobki pracowników były znacząco niższe w porównaniu do szacowanych jako minimalne, finansowych wymogów utrzymania rodziny. Przeciętne zarobki w październiku 1943 roku nie przekraczały 180-240 rubli netto miesięcznie, podczas gdy minimalna kwota na utrzymanie rodziny wyniosła 1000 rubli $^{29}$.

\section{Wnioski obywateli polskich w ZSRS do polskich władz o pomoc finansową — kazus Polaków z obszaru Uzbeckiej SRR}

Pogarszające się położenie ludności polskiej zamieszkującej odleglejsze rejony ZSRS przyczyniło się do upowszechnienia praktyki występowania do londyńskiego Rządu RP na uchodźstwie — najczęściej za pośrednictwem korespondencji kierowanej do tak zwanych mężów zaufania pracujących w placówkach podlegających polskim ambasadom rozlokowanym na obsza-

27 Sprawozdanie lekarskie W. Funka z dnia 8 października 1942 roku. Sprawozdanie mężów zaufania z irkuckiej oblasti z okresu sierpień 1942-styczeń 1943 roku, IPMS w Londynie, Ambasada RP w Kujbyszewie, A.7/307/41.

28 Ibidem. Podkreśla się, iż jako że brakowało duszpasterzy i zakazywano odprawiania publicznych praktyk religijnych, organizacją życia religijnego w rodzinach polskich zajmowały się przede wszystkim kobiety. Praktykowano modlitwy, przepisywano teksty pieśni religijnych i modlitw, śpiewano kościelne pieśni oraz wychowywano dzieci w duchu patriotyzmu nierozerwalnie związanego z przywiązaniem do religii katolickiej. P. Stolyarov-Korol, Przez Sybir do Polski, Abakan 2007, s. 36. Należy zgodzić się również ze stanowiskiem, zgodnie z którym władzom sowieckim zależało dalece bardziej na rusyfikacji oraz ateizacji dzieci i młodzieży polskich zesłańców aniżeli ułatwianiu im kształcenia w języku polskim i duchu tradycji religijnych. A. Pankiewicz, op. cit., s. 78-79.

29 Wyciąg ze sprawozdania męża zaufania, Leopolda Juzwy z dnia 31 października 1942 roku. Sprawozdania mężów zaufania z Jakuckiej ASRR z okresu luty-listopad 1942 roku, IPMS w Londynie, Ambasada RP w Kujbyszewie, A.7/307/41. 
rze ZSRS ${ }^{30}$ — o pomoc finansową w formie zapomóg (zasiłków) dla członków polskich rodzin wojskowych. Przykładowo, uwzględniając archiwalia oraz dane z 1942 roku, we wchodzących w skład Uzbeckiej SRR rejonach Past-Dargomskim pomocy udzielono 41 rodzinom $^{31}$, w rejonie Dżizak $72^{32}$, a w rejonie Dżambajskim liczbę rodzin wojskowych oszacowano na $126^{33}$, natomiast pomoc 31 rodzinom wypłacono w maju 1942 roku łącznie ${ }^{34}$. Listę kandydatów do udzielenia pomocy finansowej z obwodu samarkandzkiego w Uzbeckiej SRR ustalono na 42 rodziny ${ }^{35}$. W rejonie Komsomolskim ze stolicą w Chabarowsku pomoc przyznano w maju i czerwcu 1942 roku 30 rodzinom $^{36}$. Należy zauważyć, że zgromadzone wykazy archiwalne były w części punktów niekompletne.

Oprócz prowadzenia wykazów rodzin wojskowych, placówki dyplomatyczne Rządu RP na uchodźstwie na obszarze ZSRS gromadziły adresowane do nich indywidualne listy członków rodzin wojskowych z prośbą o przyznanie pomocy finansowej. Zachowało się kilkaset takich listów, przykładowy przedstawiono na ilustracji 1.

30 Zgodnie z informacjami z pierwszego kwartału 1943 roku można ustalić, że mężowie zaufania pełnili szczególnie ważną funkcję w rozpoznawaniu potrzeb lokalnych skupisk ludności polskiej rozsianej łącznie po 42 obwodach ZSRS i informowaniu o tych potrzebach centrali polskiego rządu emigracyjnego w Londynie. Wskazano jednocześnie, że na obszarze ZSRS znalazło się w tym okresie około 2,6 tysiąca skupisk ludności polskiej, co spowodowało konieczność powołania placówek mężów zaufania łącznie w 421 miejscowościach. P. Petlewicz, Ludność cywilna i sieroty polskie po „amnestii” 12 sierpnia 1941 r., „Zesłaniec” 2007, $\mathrm{nr}$ 32, s. 75-76. Placówki miały odpowiadać za podstawową opiekę nad polskimi obywatelami w warunkach „odwilży” w reaktywowanych stosunkach polsko-sowieckich w warunkach obowiązywania postanowień układu Sikorski-Majski z 30 lipca 1941 roku. Z danych z maja 1942 roku można wnioskować, że realizowaniem wyżej wymienionego zadania zajmowało się ponad 3 tysiące osób. A. Kaniewska, Działalność Delegatury Ambasady RP w Kraju Attajskim w latach 1941-1943, „Wrocławskie Studia Wschodnie” 2017, nr 21, s. 112.

31 Wykaz rodzin wojskowych na terenie rejonu Past-Dargomskiego [czerwiec 1942], Ambasada RP w Kujbyszewie, A.7/307/23.

32 Zapomogi dla rodzin wojskowych w rejonie Dżizak [1942], Ambasada RP w Kujbyszewie, A.7/307/21.

33 Spis rodzin wojskowych z rejonie Dżambajskim włącznie z indywidualnymi wnioskami z okresu od 5 kwietnia do 4 lipca 1942 roku, IPMS w Londynie, Ambasada RP w Kujbyszewie, A. $7 / 307 / 20$.

34 Wykazy rodzin wojskowych z rejonu Dżambajskiego, którym wypłacono zasiłki za maj 1942 [3 czerwca 1942], IPMS w Londynie, Ambasada RP w Kujbyszewie, A.7/307/20.

35 Lista kandydatów do zapomogi dla rodzin wojskowych w obwodzie Samarkanda, IPMS w Londynie, Ambasada RP w Kujbyszewie, A.7/307/24.

36 Wykaz rodzin wojskowych rejonu Komsomolskiego [czerwiec 1942], IPMS w Londynie, Ambasada RP w Kujbyszewie, A.7/307/22. 


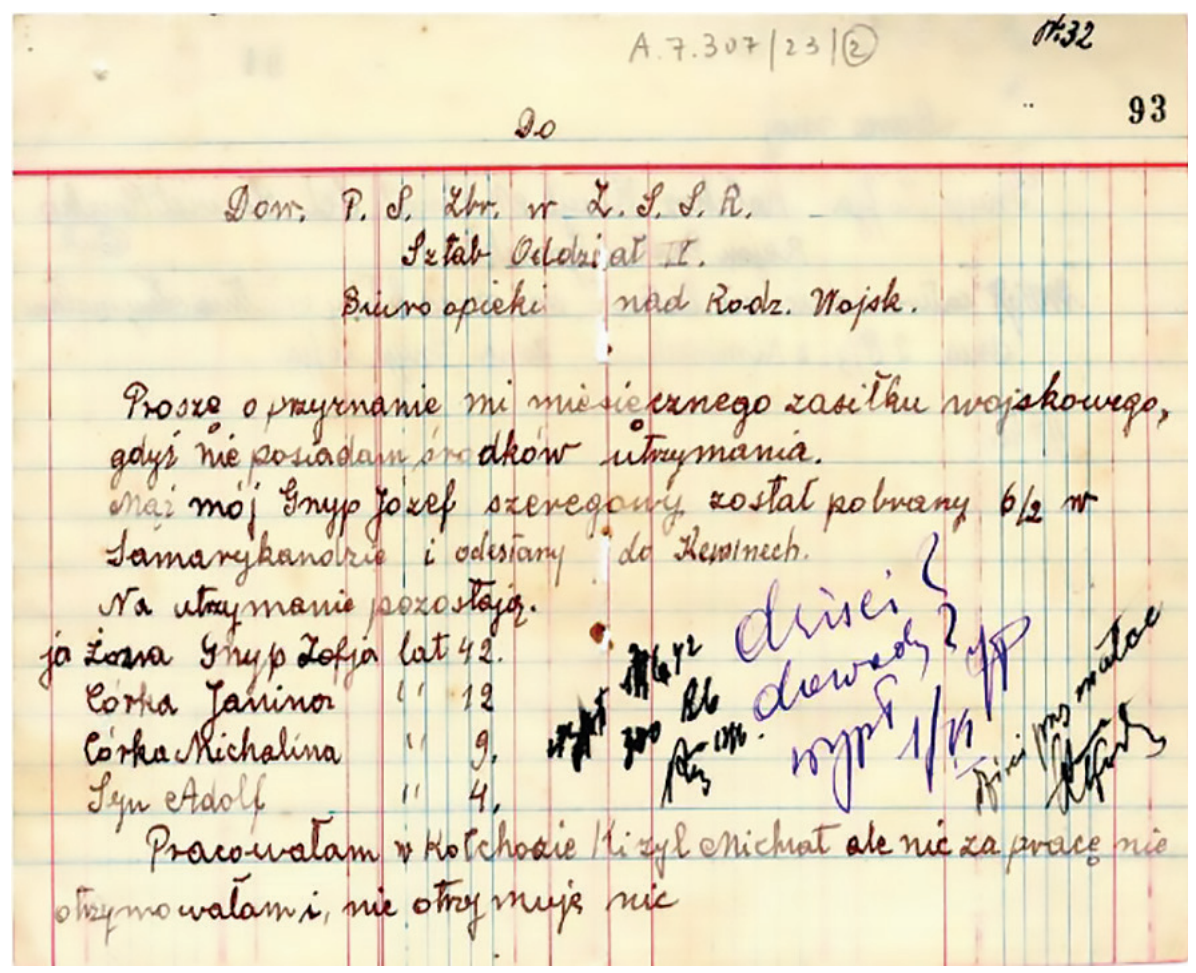

Ilustracja 1. Przykładowy indywidualny list polskiej rodziny wojskowej mieszkającej w rejonie past-Dargomskim z prośbą o przyznanie zasiłku

Źródło: Indywidualne listy rodzin wojskowych z prośbą o zasiłek [czerwiec 1942], Ambasada RP w Kujbyszewie, A.7/307/23.

Przedstawiony list potwierdza, z jak trudnymi warunkami musiały mierzyć się polskie rodziny mieszkające w odległych rejonach ZSRS. W liście wskazano na fakt wykorzystywania Polaków w pracy w kołchozach, bez pewności uzyskania płacy czy wynagrodzenia w naturze. Służba wojskowa obywateli polskich i ich rozłąka z rodziną tworzyła trudność w zaspokajaniu potrzeb codziennej egzystencji w rodzinach wielodzietnych, które nie miały środków utrzymania.

Formalne zerwanie, z inicjatywy Józefa Stalina, stosunków dyplomatycznych ZSRS z Rządem RP na uchodźstwie w kwietniu 1943 roku przyczyniło się do dalszych istotnych zmian w położeniu członków polskiej diaspory rozlokowanej w odległych rejonach ZSRS. Należy podkreślić, że były to zmiany negatywne w porównaniu do poprzedzającego je okresu organizowania opieki nad ludnością polską przy udziale placówek dyplomatycznych rządu emigracyjnego. Wznowiony od lutego 1943 roku proces paszportyzacji prowadził w praktyce do ponownego narzucenia ludności polskiej obywatelstwa 
ZSRS $^{37}$. Towarzyszyła temu likwidacja większości placówek powołanych do opieki nad ludnością polską w ramach zainicjowania przez Moskwę nowej fali represji wobec grup mniejszościowych w państwie ${ }^{38}$. Odwoływano zarazem delegatów opieki nad polskimi obywatelami w ZSRR, natomiast majątek likwidowanych placówek przejmowano na potrzeby sowieckie ${ }^{39}$.

\section{Podsumowanie i wnioski}

Argumenty wskazane w artykule pozwalają na sformułowanie kilku ogólnych wniosków płynących z analizy.

1. Działalność Ambasady RP w Moskwie, przeniesionej następnie do Kujbyszewa, była koniecznym elementem zagwarantowania pomocy obywatelom polskim, którzy znaleźli się w odległych obszarach Związku Sowieckiego w następstwie wydarzeń z lat 1939-1943.

2. Podstawowym środkiem do przedsięwzięcia działań pomocowych dla Polonii w ZSRS było utworzenie delegatur i współpracujących z nimi mężów zaufania. Równie ważną formą działań należy traktować utrzymywanie systemu zakładów opieki dla potrzebującej ludności polskiej rozsianej w odległych zakątkach Związku Sowieckiego.

3. Polacy żyjący w środkowej i wschodniej Syberii, a także w obwodach Uzbeckiej SRR zmagali się z wieloma problemami, dotyczącymi takich sfer, jak niski status materialny, głód i niedożywienie, fatalne warunki mieszkaniowe, przymus pracy lub nieadekwatne wynagrodzenie za pracę, brak podstawowych środków do życia czy niski poziom higieny i liczne problemy zdrowotne.

Przedstawione rozważania wpisują się w złożoną problematykę funkcjonowania obywateli polskich na obszarze Związku Sowieckiego w latach 1939-1943. Archiwalia wskazujące na rozmaite problemy ludności, wśród

37 W. Marciniak, Uwagi o genezie polsko-radzieckiej umowy repatriacyjnej z 6 lipca 1945 r., „Acta Universitatis Lodziensis. Folia Historica” 2013, nr 91, s. 112-113. Podstawą zmiany polityki sowieckiej wobec ludności polskiej była decyzja Kremla z dnia 16 stycznia 1943 roku, na mocy której wyłącznie władze sowieckie miały decydować o obywatelstwie osób przebywających na terytorium ZSRS. Rejestrację obywateli polskich dla potrzeb ewidencji ludności i nadawanie im obywatelstwa ZSRS poprzedzało odebranie dotychczasowych dowodów osobistych. B. Sztubarska, Zarys dziatalności konsularnej Ambasady RP w ZSRR w latach 19411943, „Studia z Dziejów Rosji i Europy Środkowo-Wschodniej” 38, 2003, s. 286.

38 D. Boćkowski, Czas nadziei..., s. 12. Sowieci likwidowali przy tym polskie magazyny z podstawowymi towarami pierwszej potrzeby dla zesłańców. Zamknięto na przykład magazyny w Archangielsku, Aszchabadzie, Mamlutce czy Samarkandzie, co doprowadziło do niekorzystnych zmian w aprowizacji ludności polskiej, zwłaszcza dla ludności z północnych obwodów ZSRS, całkowicie zdanej na żywność, leki i odzież przechowywaną w magazynie w Kirowie. Akcja represyjna objęła aresztowanie części polskich mężów zaufania podejrzewanych o działalność na szkodę interesów sowieckich. Ibidem, s. 237.

39 M. Stopikowska, Wychowanie Polaków na zesłaniu w ZSRR, Lublin 2001, s. 89.

Wrocławskie Studia Wschodnie 24, 2020

(C) for this edition by CNS 
której dużą grupę tworzyli zesłańcy, są cennym zasobem wiedzy dla współczesnego historyka zajmującego się szerzej rozumianą problematyką wschodnią w odniesieniu do sprawy polskiej podczas II wojny światowej.

\section{Bibliografia}

\section{Źródła archiwalne}

Deportacja Litwinów z wydawnictwa „Russian Affairs” [październik 1944] z dnia 20 grudnia 1944 roku, AIJP w Ameryce, Samodzielna Placówka Wywiadowcza ESTEZET, teczka: 701/111/16.

Lista kandydatów do zapomogi dla rodzin wojskowych w obwodzie Samarkanda, IPMS w Londynie, Ambasada RP w Kujbyszewie, A.7/307/24.

Położenie ludności polskiej w środkowej Syberii. Sprawozdanie z dnia 29 marca 1943 roku, IPMS w Londynie, Ambasada RP w Kujbyszewie, A.7/307/42.

Położenie ludności polskiej we wschodniej Syberii. Sprawozdanie z dnia 28 lutego 1943 roku, IPMS w Londynie, Ambasada RP w Kujbyszewie, A.7/307/41.

Protokoły Komisji dla Spraw Sowieckich. Depesze do placówek, IPMS w Londynie, Prezydium Rady Ministrów. Archiwum Kancelarii 1939-1990, PRM.K. 19.

Spis rodzin wojskowych z rejonie Dżambajskim włącznie z indywidualnymi wnioskami z okresu od 5 kwietnia do 4 lipca 1942 roku, IPMS w Londynie, Ambasada RP w Kujbyszewie, A.7/307/20.

Sprawozdanie Działu Opieki Społecznej Ambasady RP w ZSRR na dzień 1 grudnia 1942 roku, IPMS w Londynie, Ambasada RP w Kujbyszewie, A.7/307/43.

Sprawozdanie A. Pająka, delegata Ambasady RP w ZSRR na Jakucką ASRR, za okres 19 września 1941-31 stycznia 1942 roku, IPMS w Londynie, Ambasada RP w Kujbyszewie, A.7/307/5.

Sprawozdanie lekarskie W. Funka z dnia 8 października 1942 roku. Sprawozdanie mężów zaufania z irkuckiej oblasti z okresu sierpień 1942-styczeń 1943 roku, IPMS w Londynie, Ambasada RP w Kujbyszewie, A.7/307/41.

Tłumaczenie artykułu pt. Deportacje we wschodniej Europie z wydawnictwa „Russian Affairs” [marzec 1945] z dnia 4 kwietnia 1945 roku, AIJP w Ameryce, Samodzielna Placówka Wywiadowcza ESTEZET, teczka: 701/111/17.

Udzielona pomoc i opieka nad ludnością żydowską w ZSRR [sierpień 1943], IPMS w Londynie, Ambasada RP w Kujbyszewie, A.7/307/40.

Wyciąg ze sprawozdania męża zaufania, Leopolda Juzwy z dnia 31 października 1942 roku. Sprawozdania mężów zaufania z Jakuckiej ASRR z okresu luty-listopad 1942 roku, IPMS w Londynie, Ambasada RP w Kujbyszewie, A.7/307/41.

Wykaz zakładów opieki Ambasady RP w ZSRR z dnia 16 lutego 1943 roku, IPMS w Londynie, Ambasada RP w Kujbyszewie, A.7/307/31.

Wykazy rodzin wojskowych z rejonu Dżambajskiego, którym wypłacono zasiłki za maj 1942 [3 czerwca 1942], IPMS w Londynie, Ambasada RP w Kujbyszewie, A.7/307/20.

Wykaz rodzin wojskowych rejonu Komsomolskiego [czerwiec 1942], IPMS w Londynie, Ambasada RP w Kujbyszewie, A.7/307/22.

Wykaz rodzin wojskowych na terenie rejonu Past-Dargomskiego [czerwiec 1942], Ambasada RP w Kujbyszewie, A.7/307/23.

Wykaz stanu liczebnego i rozmieszczenia obywateli polskich w ZSRR w poszczególnych rejonach dnia 25 kwietnia 1943 roku, IPMS w Londynie, Ambasada RP w Kujbyszewie, A.7/307/30.

Wrocławskie Studia Wschodnie 24, 2020

(C) for this edition by CNS 
Wykaz zakładów opieki Ambasady RP w ZSRR z dnia 16 lutego 1943 roku, IPMS w Londynie, Ambasada RP w Kujbyszewie, A.7/307/31.

Zapomogi dla rodzin wojskowych w rejonie Dżizak [1942], Ambasada RP w Kujbyszewie, A. $7 / 307 / 21$.

\section{Dokumenty i źródła publikowane}

Archiwalia Ambasady RP w Moskwie-Kujbyszewie (1941-1943) i Ministerstwa Informacji i Dokumentacji (1939-1945) w zbiorach Instytutu Hoovera w Stanfordzie. Informator, oprac. M. Filipiak, Warszawa 2002.

Mały Rocznik Statystyczny Polski. Wrzesień 1939-czerwiec 1941, Londyn 1941.

Polacy w łagrach rosyjskiej pótnocy. W świetle relacji, listów i dokumentów, oprac. H. Owsiany, Warszawa 2000.

\section{Opracowania}

Bereza T., Represje NKWD wobec mieszkańców strefy przygranicznej 1939-1941, „Biuletyn IPN" 2001, nr 7.

Boćkowski D., Czas nadziei. Obywatele Rzeczypospolitej Polskiej w ZSRR i opieka nad nimi placówek polskich w latach 1940-1943, Warszawa 1999.

Boćkowski D., Dyplomacja Rzadu Drugiej Rzeczypospolitej na uchodźstwie wobec kwestii polskiej w ZSRR w latach 1939-1945, [w:] Z dziejów polskiej służby dyplomatycznej i konsularnej, red. J. Faryś, M. Szczerbiński, Gorzów Wielkopolski 2005.

Boćkowski D., Działalność ambasady RP w Kujbyszewie oraz jej delegatur i placówek mężów zaufania w świetle raportów NIK Rządu RP w Londynie, „Studia z Dziejów Rosji i Europy Środkowo-Wschodniej” 32, 1997.

Boćkowski D., Masowe deportacje polskiej ludności w głąb ZSRR w latach 1940-1941: próba weryfikacji danych, „Mazowieckie Studia Humanistyczne” 1996, nr 2/1.

Brewczyńska-Wiktor U., Mniejszość polska w Rosji-geneza i współczesność, „Studia i Badania Naukowe. Europeistyka" 2014, nr 2.

Buczek R., Działalność opiekuńcza Ambasady RP w ZSRR w latach 1941-43, „Zeszyty Historyczne" 1974, nr 29.

Ciesielski S., Polacy w Kazachstanie 1940-1946. Zestańcy lat wojny, Wrocław 1997.

Ciesielski S., Hryciuk G., Warunki egzystencji, [w:] Życie codzienne polskich zesłańców w ZSRR w latach 1940-1946, red. S. Ciesielski, Wrocław 1997.

Czerniakiewicz J., Przemieszczenia ludności polskiej z ZSRR 1944-1959, Warszawa 2004.

Czubiński A., Dzieje najnowsze Polski do roku 1945, Poznań 1994.

Dobroński A.C., Raport o Polakach na południu Kazachstanu, „Zesłaniec” 2008, nr 35.

Eberhard P., Geografia ludności Rosji, Warszawa 2002.

Eberhardt P., Skład narodowościowy ludności Federacji Rosyjskiej na przełomie XX i XXI wie$k u$, ,Studia z Geografii Politycznej i Historycznej” 5, 2016.

Iwanow M., Polonia w Związu Radzieckim okresu międzywojennego. Kontrowersje wokót liczebności, „Dzieje Najnowsze” 19, 1997, nr 4.

Jasiewicz K., Europa nie prowincjonalna. Przemiany na ziemiach wschodnich dawnej Rzeczypospolitej w latach 1772-1999, Warszawa 1999.

Kaniewska A., Działalność Delegatury Ambasady RP w Kraju Altajskim w latach 1941-1943, „Wrocławskie Studia Wschodnie” 2017, nr 21.

Kersten K., Szacunek strat osobowych w Polsce Wschodniej, „Dzieje Najnowsze” 24, 1994, nr 2.

Wrocławskie Studia Wschodnie 24, 2020

(C) for this edition by CNS 
Krochmal A., Polacy i polskie dziedzictwo kulturowe w krajach Europy Wschodniej (cz. 6). Sytuacja Polaków od rewolucji bolszewickiej do 1939 r., „Cenne. Bezcenne. Utracone” 2008, nr 1.

Kubiak H., Mniejszości polskie i Polonia w ZSRR, Wrocław 1992.

Kwiecień M., Kilka dokumentów z dziejów ruchu prometejskiego lat drugiej wojny światowej, „Krakowskie Studia z Historii Państwa i Prawa” 7, 2014, nr 2.

Lachowicz J., Los dzieci polskich w ZSRR w czasie II wojny światowej, [w:] Położenie ludności polskiej na terytorium ZSRR i wschodniej ziemiach Rzeczypospolitej w czasie II wojny światowej, red. A. Marszałek, Toruń 1990.

Landmann T., Prometeizm jako założenie polityczno-ideologiczne w korespondencji Polskiej Grupy Prometeusza w Londynie w pierwszych latach po II wojnie światowej, „Wschodnioznawstwo" 2018, nr 12.

Leończyk S., Mała Minusa w Kraju Krasnojarskim jako miejsce pamięci deportacji narodu polskiego, „Niepodległość i Pamięć” 2017, nr 1.

Łukasiewicz S., Prometeizm na emigracji w pierwszych latach po II wojnie światowej w świetle materiałów wywiadu komunistycznego Polski Ludowej, [w:] Ruch prometejski i walka o przebudowę Europy Wschodniej (1918-1940). Studia i szkice, red. M. Kornat, Warszawa 2012.

Marciniak W., Uwagi o genezie polsko-radzieckiej umowy repatriacyjnej z 6 lipca 1945 r., „Acta Universitatis Lodziensis. Folia Historica” 2013, nr 91.

Maryański A., Przemiany ludnościowe w ZSRR, Warszawa 1995.

Matelski D., Polityka eksterminacji obywateli Drugiej Rzeczypospolitej przez Trzecia Rzesze $i$ Zwiazek Sowiecki w latach 1939-1945, „Nowa Polityka Wschodnia” 2017, nr 4.

Pankiewicz A., Sytuacja polskich zesłańców na Syberii w okresie II wojny światowej, „Zesłaniec" 2016, nr 66.

Patek A., Polska diaspora w Rosji Radzieckiej i ZSRR, [w:] Polska diaspora, red. D. Bartkowiak, A. Walaszek, Kraków 2001.

Petlewicz P., Ludność cywilna i sieroty polskie po ,amnestii” 12 sierpnia 1941 r., „Zesłaniec” 2007, nr 32.

Siedlecki J., Losy Polaków w ZSRR w latach 1939-1986, Londyn 1988.

Srebrakowski A., Liczba Polaków w ZSRR w świetle oficjalnych statystyk, [w:] Mniejszości narodowe i religijne w Europie Środkowo-Wschodniej w świetle statystyk XIX i XX wieku, red. J. Skarbek, Z. Sułowski, Lublin 1995.

Stolyarov-Korol P., Przez Sybir do Polski, Abakan 2007.

Stopikowska M., Wychowanie Polaków na zesłaniu w ZSRR, Lublin 2001.

Sztubarska B., Zarys działalności konsularnej Ambasady RP w ZSRR w latach 1941-1943, „Studia z Dziejów Rosji i Europy Środkowo-Wschodniej” 38, 2003.

Śladkowski W., Wychodźstwa polskiego zarys dziejowy, Lublin 1994.

Wieliczko M., Rozpoznanie przez Polski Czerwony Krzyż losu Polaków w Związu Radzieckim (listopad 1939-lipiec 1941 roku), [w:] Mniejszości polskie i Polonia w ZSRR, red. H. Kubiak, T. Paleczny, J. Rokicki, M. Wawrykiewicz, Kraków-Warszawa-Wrocław 1992.

Wyszczelski L., Rozpruwanie Rosji. Prometeizm - idea i realizacja, Warszawa 2016. Żaroń P., Armia Polska w ZSRR, na Bliskim i Środkowym Wschodzie, Warszawa 1981.

Żaroń P., Ludność Polska w związku radzieckim w czasie II wojny światowej, Warszawa 1990. 